\title{
Organized Fan Groups and Sports Journalism in Brazil: A Social History of Soccer Fans in the City of Rio de Janeiro
}

\author{
Bernardo Buarque de Hollanda \\ Getulio Vargas Foundation (FGV) - The Social Sciences School - São Paulo, Brazil
}

\begin{abstract}
The article focuses on sources of Brazilian sports journalism and demonstrates the role of organized soccer fan groups in Rio de Janeiro between the 1940s and 1980s, this is achieved through reports provided by the Brazilian newspaper Jornal dos Sports. From the beginning, there are biographical notes made about the most well-known fan leaders in Rio, such as Jaime de Carvalho, who founded the Charanga (1942). The emergence of dissent among the fans, in the late 1960s, is then covered, which establishes itself within the organized fans in Rio with these individuals beginning to question the authority of the old fan group leaders. This is against the principle of giving unconditional support to the club and it is postulated that the fans have the right to criticize and protest against the club's management, even if this means using forceful tactics. Along with the journalistic narrative, there is a break-off by the "Young Fans" and a process of emancipation begins which occurs over the 1970s, this happens by means of the use of fan coaches and the invention of a lifestyle that is associated with soccer. Finally, the 1980s is marked by the constructive and destructive potential that is linked to fan groups. On the one hand, creating an Association of fans-Astorj-is pointed to in order to reach a mutual understanding, but it should be noted, on the other, that there are feuds, in a scenario of spiraling violence, in which fights, beatings, and even murders begin to be commonplace.
\end{abstract}

Keywords: Brazilian soccer history, supporters' groups, youth, culture, politics in the 1960s

\section{Introduction}

This article is based on the Historical Archive from the Jornal dos Sports, by means of consulting its publications from the 1960s, 1970s, and 1980s. The research sources used were press material related to soccer fans and to organized supporter organizations, especially regarding the group known as Torcidas Jovens (Young Fans). This is because these fan groups, who appeared in the late 60s, are still the largest groups of soccer fans of teams in Rio de Janeiro today, namely, Flamengo, Fluminense, Vasco and Botafogo, to which thousands of young people from many social classes and different regions in the city and in the country are affiliated. On the other hand, these are groups that the public identifies as being most responsible for promoting and inciting violence in soccer, giving them the image of thugs, hooligans, and troublemakers.

Understanding the historical dynamics of how these youth groups emerged is of interest. The central argument, which is covered in the second part of this text, is that the fan groups went through a power struggle within the club and the fan environment itself, the objective of which to try to legitimize itself based on generational ties with the leaders of older supporter groups. These supporter organizations, known as the

\footnotetext{
Bernardo Buarque de Hollanda, Ph.D., Social History, Pontifícia Universidade Católica (PUC-Rio de Janeiro).
} 
"Charangas", were the first group of organized supporters to emerge in Brazil, in the early 1940s.

Another event, led by the "Torcidas Jovens", took place within the administrative sphere of the clubs, in particular with the short-sighted, amateurish managers Challenges to the club President led to his authority being questioned and the desire to appease the supporters by changing coaches and players. The unconditional support the Club, which was defining trademark of the first organized supporters, began being questioned, with the right to demonstrate the dissatisfaction felt by the young fans.

The adopted procedure was to undertake a systematic reading of the main sports periodical of the time in Rio de Janeiro, the Jornal dos Sports, written by the journalist Mário Filho. The editions published between 1967 and 1984 were followed every day. In order to apply methodical and scientific scrutiny, the news about the fans were divided and systemized into six main parts, according to the newspaper's information structure: (1) the front-page headlines; (2) editorials; (3) special reports; (4) daily coverage of the clubs; (5) the visual parts, including cartoons and pictures; (6) the readers' letters section.

In the Historical Archive of the journal, it was still possible to access a large number of published and unpublished photos on the fans, with the discovery of unpublished sources and information that has been quite inaccessible. Several files were identified under the heading "Torcidas", in which there were some relationships noted between journalists and fan leaders that are not included in the newspaper, but refer to mediations and spaces given to the fan groups of that time.

As these are more than merely a source of information, the periodicals were treated as social constructs of reality, which is in line with the studies on the "history of the press". The newspaper was considered to be a strategic social actor in the development of the image of these groups. In particular, this was the case with the paper by the entrepreneur Mário Filho (1908-1966), the Jornal dos Sports, which was created in 1931. In his newspaper, the pedagogical guidelines of the sport became connected with its commercial interests. This made the paper adopt a strategy of valuing the public, the opinion of the crowd, and the idea of the individual fan, while there was also the perception of the club being owned by the consumers themselves.

The serialized survey of information in the newspaper made it possible to identify three key moments for the "Torcidas Jovens", which correspond to the political-historical period under study: a) the first moment being the year 1968; b) the second derving from the Institutional Act number five (AI-5) in the mid-1970s, during the so-called "Anos de Chumbo-Years of Lead" by the military dictatorship; c) the third covering the "Tempo das Aberturas - Time of Openings", which went from the late 1970s to the early 1980s.

Thus, the image of these groups initially had a sense of youth identity linked to the idea of avant-garde and opposition. Secondly, the group appears to be a "hedonist" space, i.e., a way of meeting and congregating with the focus being on fun, which includes transgressions and obscene songs being sung on the traveling coach. Thirdly, the group presents themselves as an organization with a rightful claim for a place in the world of soccer. In guidelines that are similar to those by trade unions, namely the demand for usurped rights, and those by the "League of Samba Schools" that are sociability, leisure and, competition, the fan groups develop having these associative types as a model, depending on that context of national life.

How this process was engendered is panoramically evidenced below. Thus, there are three main parts. The first is dedicated to the symbol of the fan, in particular to a specific character, the leader of the fan group; the second part outlines an historical panel of how the "Torcidas Jovens" emerged; the third and final part looked to highlight the symbolic and material aspects that characterize these associations that were built over time. 


\section{The Invention of the "Organized Fan Group Leader"}

In Brazil, the emergence of soccer dates back from the turn of the 19th century to the 20th century. In its early days, soccer was a practice only undertaken by children of the wealthy Brazilian elite. Over the years, the sport grew very quickly; in the 1910s this activity became associated with a specific audience: those who were interested in the game and looked to congregate on the outskirts of the fields, when such areas were accessible. In the 1030s, with the institutionalization of soccer and its transformation into a professional activity and a sporting spectacle, large stadiums were built.

With there being no previous references or any sports writing language itself, this audience was initially associated with broader theoretical discussions regarding the symbol of spectator sports. The debate was not a new one and dated back to the concept of the spectator in the arts. This was especially true regarding the idea of catharsis in the theater and its importance in Western tradition, from A poética, by Aristotle ${ }^{1}$. Based in this, catharsis-the purging of emotions-is the explicative matrix from the base of the Greek tragedy.

At the height of the Roman Empire, the image of plebeian amusements, which is summed up in the famous motto panis et circensis (Bread and Circus), also contributed to providing a base to what later became defining expressions and functions of soccer in the social imagination. The purpose here is not to create exhaustive lists. It is sufficient to cite current expressions from popular jargon, such as "escape valves", "opium of the people" and "alienation of the masses". These would be incorporated into the vocabulary for sporting spectacles, as soccer grew in the city. Soccer's appropriation by the popular classes will be decisive, along with it losing its elitist character distinction.

From a historical point of view, the audience of the popular sports is precisely those who will reverse the passive image of spectators of the aristocratic and bourgeois arts, in particular those developed in the Courts of European society, from the 17 th and 18 th centuries, as was shown by German sociologist Norbert Elias ${ }^{2}$. This adheres to the rules of etiquette demonstrated by the audience's applause following a performance of a piece of classical music in a theater or opera house.

In the 20th century, the advent of sports such as boxing, which was extremely admired by Bertolt Brecht ${ }^{3}$, makes the audience assume an active image of influence, involvement, and intervention in the dynamics of the game. The make-up of its structure is open, which results in an uncertainty that stimulates interference from the public. With the ending being unknown by the protagonists themselves, unlike the theater, the game imprinted this participatory dimension to sporting spectacles.

By following and analyzing the language used by the sports press, it is possible to exemplify this change in direction. At first, the soccer public in Brazil was initially known by the term "support", which resembles the expression of the theater's "audience". Support is only made up by those that watch the game. Little by little, the participation and the role of the soccer audience within the fan groups - through continuous comments, shouting, and applause - transformed this passive condition. The 1920s ratified this change, with the word "supporter" emerging.

Along with its emergence, the term still retained an image of nobility. The word was coined by Coelho Neto, writer of the belle époque carioca, which refers to an individual who supports a team. Better: the

\footnotetext{
1 Aristóteles. Arte retórica e arte poética. Rio de Janeiro: Ediouro, s.d.

2 Elias, N.; Dunning, E. A busca da excitação. Lisboa: Difel, 1995.

3 Bornheim, G. Brecht, a estética do teatro. Rio de Janeiro: Graal, 1992.
} 
individual who waves the scarf has the door in his hands. The image is constituted from a female audience, who waves the cloth prop in times of distress and who contorts her own body with this effect. The supporters express in their body whatever uncertainties are happening on the field of play.

It is then possible to follow the appearance of the figure to represent the fans, a character that was missing in the early days of soccer elitists. By giving special attention, the emergence of a particular kind of figure in the sports press can be observed: the organized fan group leader. The leader became one of the main characters in the sport's "moral framework", as it was referred to by Luiz Henrique de Toledo ${ }^{4}$ for Era Vargas (period in Brazil between 1930-1945), which is present in the newspaper of Mário Filho.

In the 1930s the representative for the fans was initially known through a diplomatic metaphor: the "Ambassador". In soccer, in Rio de Janeiro, the ambassador was a supporter and a club representative who was elected by the newspaper's readers. The candidate who received the most votes was sent as representative of the Brazilian fans in the World Cup that began in that decade. In 1938, for example, two "ambassadors" earned a trip to represent Brazil and attend the World Cup in France, after being chosen following a test held by the Jornal dos Sports.

In the early 1940s, these leaders became institutionalized. This decade marks the appearance of the Charangas and the organized fans. It was during this period that the fan representative became being referred to as the "leader" by the press. This nomenclature was an extension of the figures of authority and discipline that were present in other areas of society at that time: chief of police, head of the family, head of State, department head, among other common names.

Based on the materials produced by the newspaper, it is possible to follow some of the biographical elements of the first fan leaders in Rio. Firstly, they were almost all immigrants from Minas Gerais (such as Tarzã, for Botafogo), São Paulo (such as Paulista, for Fluminense) or the Northeast (such as Jaime de Carvalho, for Flamengo), who were mostly from the popular classes.

The socioeconomic profile of fan leaders from Rio contrasted with the uniformed fan leaders in São Paulo of the time. Primarily, these are from the clubs and, therefore, from the São Paulo elite of the time. A fact worth mentioning is that, in São Paulo, the uniformed fans were born from trips undertaken by students from Law Schools to the United States of America. In a statement made by Alberto Helena Jr., cited by researcher Elizabeth Murilho da Silva ${ }^{5}$, in the U.S.A., they understand the strength of college sports and imported the kind of support and excitement seen in North American audiences to São Paulo.

From the first generation of fan group leaders that appeared in Rio soccer, the best known character was Jaime de Carvalho (1912-1976).

He was originally from Bahia, but settled in Rio de Janeiro in 1927, and spent his whole life working as a civil servant at the Ministry of Justice where he was a concierge. In 1942, he created the Charanga do Flamengo, a fan group that he led until 1976, the year in which he died. In 1950, he became known in the city as the fan leader for the Brazilian national team at the World Cup, which was held in Brazil. Being sponsored by Mário Filho, he traveled to the Switzerland World Cup in 1954, and the Germany World Cup in 1974, which was two years before he died.

\footnotetext{
${ }^{4}$ Toledo, L. H. de. Lógicas no futebol. São Paulo: HUCITEC, 2002.

5 Silva, E. M. da. "A violência no futebol e a imprensa esportiva”. In: COSTA, M. R.da (Org.). Futebol, espetáculo do século. São Paulo: Musa Editora, 1999.
} 
Coming from the popular classes - builders, servants, low-level workers - the fan leaders from the 50s could be recognized by their economic modesty and colorful costumes in the stadiums: a bell, a horn, a whistle, a flag, some kind of object or prop that made it exotic and caught the eye. Because of this, in the first phase of the professionalism in Brazil, between the 1930s and 1960s, the fan leaders would be an object of exaltation for the writers. They were seen as authentic expressions of passion for their clubs, embodying Christian virtues-simplicity, altruism, generosity, and sacrifice.

The humble speech, from the Franciscan tradition of Christianity, is present in the words of sportswriters, when they romanticized and spoke of these fans, altruism being their trademark.

The fan leaders thus had a dual mission on the soccer field. One was pedagogical: to cooperate with the police in order to organize the masses in the public space from the increasingly large stands. The Laranjeiras stadium was built to hold 20 thousand fans, while the São Januário stadium was twice as big, holding 40 thousand. The Maracanã, which opened in 1950, was the largest arena, with a stadium capacity of 200 thousand.

The other mission for the fan leader was to be the quintessence of amateur purity in soccer, in a universe that was becoming increasingly professionalized and commercialized. Although the term "fan leader" would go on until the 1980s - varying from boss or president years later, its meaning would become considerably altered from the 1960s onwards.

The romanticized vision of the writer suffered a setback in this second phase of the professionalism, at the same time as the Brazilian Soccer League, the television broadcasts and the Young Supporters emerged. From the part of the sportswriters, the exaltation turned into anger, as the scenery changed and the fighting intensified. In the late 1960s, the number of fan leaders at each club multiplied. This broke with the authority of the leader from the 1940s, up to which time the principle had been established: one club, one fan group, one fan leader. There now appeared new leaderships, with new profiles and new interests. Over time, in the eyes of the writers, these leaders clashed with the amateur ethos, which were up to then considered as being intrinsic to the profile of the soccer supporter.

The purity and abnegation was replaced with ambition, the desire to benefit economically and financially. The fan leaders began establishing a kind of ambiguous relationship with the club management, who were known by the pejorative epithet "top hats". The leaders got these political and economic benefits. In return, they offered protection and support for the clubs' internal politics. There was a kind of "corrosion of the character" of the fan. Before this time the fan was simple, naïve, and amateurish, over the years this view was corrupted by the professional and financial developments in soccer.

Thus, previously the preserver of the order in the stands, the fan leader became a promoter of problems in that area. Their participation in the clubs' political life, as a kind of enforcer or bodyguard for the leaders, shows the degradation of their original purpose. One writer illustrates the argument in an exemplary manner:

Long gone are the times when the stands of the Maracanã hosted a great and joyful event encouraged by the red and black charanga of Jaime or the talo de mamão of Ramalho from Vasco. Today, the organized fans, like everything else that surrounds us, also focus on violence. The goals are increasingly rare on the pitch, and the fans enjoy these long time period to assault one another. They throw objects at the players, their disorder is more appropriate for the police pages than those that recorded in this noble British sport. They say that they embellish the sporting spectacle with their colorful flags and screaming, supporting the team in far away stadiums, and who are fighting against the increase in ticket prices. However, the families want these 'angels' to go away, and each time further away from the stadiums. Club journalists and directors accuse the fan leaders of professionalism and using their position for personal gain. It was this tense story, from 
the stands where fan passion increasingly needs more and more police cordons to control them, which reporters Mauro Ventura, Sidney Garambone and Marcelo Gomes found in Rio stadiums and put on the cover of this edition. Today there is Flamengo v Fluminense. Be careful. ${ }^{6}$

By observing this reversal of treatment by the journalist towards the fans, which changed from exaltation to condemnation, it is possible to see that this debate is not confined only to the world of soccer. Even implicitly, this controversy has direct connections with the social life and refers to a long tradition of discussion surrounding Brazilian Social Thought. They date back to the so-called "interpreters of Brazil", the character of Brazilian men and the formation of the State and of national institutions.

Despite not being stated in academic terms, the diagnosis by journalists regarding the moral crisis in soccer, also expressed in the case of the fan leaders' behavior, presupposes the idea of the "late" Iberian-American, in the face of the Anglo-Saxon Nordic world. In the Weberian discussion on Brazilian culture, made by Sérgio Buarque, Raymundo Faoro and Roberto DaMatta, among others, this archaic background would result in a "perverse chemistry", according to anthropologist Luis Eduardo Soares .

This is the result of combining an authoritarian way of capitalistic development and a legacy of the hierarchical cultural model from Portuguese colonialism. It can be schematically said that the hierarchy between upper and lower classes, which is the legal basis for the colonial world, will not disappear by introducing horizontal capitalist, democratic and republican relationships. In the cities, the wave of modernization does not cancel out the "favor of logic", i.e., the personal favoritism that is based on non-universal criteria, according to the convenience of the parties and their vested interests.

The public-private mix is not only evident at institutional level but, above all, exists within the framework of social customs and daily life. The common sense of journalists will incorporate a version of the so-called "Brazilian dilemma" into their discourse. In the relationship between the club management and the fan leader, they will detect a political culture of the personal benefitting at the expense of the common good. This "culture" would be one of the obstacles for developing citizenship and capitalism in Brazil, based on a long tradition of violence, fraud, and nepotism.

In the field of sports language, this discussion will be oriented in terms of amateurism/professionalism opposition. It can be exemplified in the ambiguous and dependent relationship between these two characters in soccer. The tutelage and cooptation of fan leaders by the club management reflect a hierarchy of who is at the bottom and who is at the top of the pyramid.

The soccer club becomes an instance of expressing national identity, with its virtues and vices. Founded by European migrants and aristocratic families in the early $20^{\text {th }}$ century, the clubs from Rio have grown with government help, who granted them land in the city's southern zone. The clubs were vehicles of the values and controversies from the broader side of society.

Despite it not being clear whether or not they knew it consciously, journalists would repeat their certain way to diagnose the "interpreters in Brazil". With their position on the pitch-they are the experts, as Bourdieu $^{8}$ defines - allows the sports commentators to denounce the dark alliances between the fan leader and

\footnotetext{
${ }^{6}$ Jornal Do Brasil. Torcidas Organizadas: as gangues da paixão. Rio de Janeiro, 22 de maio de 1988, Suplemento Especial Revista de Domingo, p. 11.

7 Soares, L. E. "Uma interpretação do Brasil para contextualizar a violência". In: PEREIRA, C. A. M. (et. al). Linguagens da violência. Rio de Janeiro: Rocco, 2000.

${ }^{8}$ Bourdieu, P. Questões de sociologia. Rio de Janeiro: Marco Zero, 1983.
} 
the club management. Certain journalists justified the national gap between the Brazilian management model and that of European soccer with this, which had been rationalized and bureaucratized.

When talking about the inability to implement a professional mindset in Brazilian soccer, they were talking about the difficulty for adopting a "protestant ethic" and a "capitalist spirit" in Brazil.

\section{The Construction of a Social Actor: The Case of the Torcidas Jovens (Young Fans) in Rio De Janeiro}

The second part of this article focuses on notes from the history of the "Young Fans" in Rio de Janeiro, between the late 1960s and early 1980s. The case of the newspaper Jornal dos Sports will still be used for following how these associations were formed. Beginning here, directly, with some clues suggested in the essay written by anthropologist José SérgioLeite Lopes. The author has remarked the role of the journalist Mário Filho in the soccer professionalism campaign ". Particulary, the idea is to take up and continue with the "intrigue" surrounding his description of the Rodrigues family, while extending the discussion to the context of forming of a soccer public in the city of Rio de Janeiro.

The plot revolves around a family drama, which is originally narrated by Rui Castro in the biography of Mário Filho's brother, Nelson Rodrigues ${ }^{10}$. Based in Pernambuco, the Rodrigues brothers were known not only for reporting the news, but also for creating it and tragically being its target.

This happened in the late 1920s, with the murder of a reporter, and promising artist, Roberto Rodrigues, in the newsroom of his father's newspaper, after yet another sensational story had been published in the newspaper against a Lady from the elite society in Rio. Months later, the father of the murdered young man, Mário Rodrigues, died as a result of illness. In a seminal essay, Leite Lopes retraced Mário Filho's biography and showed his ability to rehabilitate socially the family through sports and the sports press.

In order to enhance sports journalism, which was a secondary concern in the media until then, he began the sports section of the newspaper $O$ Globo. He then gambled by buying a periodical that was dedicated to sports, which was in keeping with the tradition of sports newspapers in Italy and France. He still worked to defend and promote professionalism in soccer, with black players and workers playing roles in the big clubs. The analysis by José Sérgio goes from 1936, when the paper was purchased, up to the death of the journalist in 1966, shortly after the World Cup in England.

Subsequently, the adopted time frame continues with the plot, with the expansion of the narrative regarding the newspaper after Mario Filho's death.

Mario Júlio Rodrigues was Mário Filho's sole heir. He continued his father's commercial project. MárioJúlio proceeded, for example, with the duelo de torcidas(duel of fans), which was a contest that followed the evaluation model used by the Brazilian Samba Schools: a jury made up of writers judged the fan groups according to traits such as animation, originality, costume, percussion, among others. The parade of the Samba Schools and the duel of the fans were both idea coming out of Mário Filho's newspapers.

At the end of the 1960s, Mário Filho's son went through financial crises while running the newspaper. Added to this was the repression of the military dictatorship, which intensified censorship and persecution after the Decree of AI-5, on December 13th, 1968. In addition, Mario Júlio had to face new family tragedies, such as the suicide of his mother, Célia Rodrigues, which happened one year after the death of her husband, Mário Filho.

\footnotetext{
9 Lopes, J. S. L. “A vitória do futebol que incorporou a pelada”. In: Revista USP - dossiê futebol. São Paulo: 1994.

${ }^{10}$ Castro, R. O anjo pornográfico - a vida de Nelson Rodrigues. São Paulo: Companhia das Letras, 1992.
} 
However, at that point in time, the symbolic power of youth was already a national and international reality and was also present in soccer as well as in the stands. As an innovation that was inspired by his father's example, MárioJúlio incorporated the "young wave" to his editorial discourse and to the newspaper's commercial strategy. This is because students and young people were generally its main readers.

The Cor-de-Rosa, as the Jornal dos Sports was popularly known, proclaimed itself "the newspaper of Youth Power". The newspaper sought to put itself alongside students, with news published about the marches and assemblies of the student movement. It gave space for cultural interests-music, theater, cinema, science, television, and the arts. By doing so it surpassed the simple label of a sports newspaper, the objective of which is to incorporate a broader audience.

At that end of the 1960s, the newspaper was hiring artists and young journalists, such as Henfil, Zuenir Ventura, Jaguar, TorquatoNeto, AnaArrudaCallado, who would later become important figures in the Brazilian cultural scene. It was an open vehicle, a place of free experimentation for aspiring individuals from journalism school which were then growing. Following these trends, the booket $O S o l$ appeared in the Cor-de-Rosa, which was one of the emblems from the 1968 generation and was portrayed in Caetano Veloso's song, "Alegria, alegria" (Joy, happiness).

This strategy of interacting with the youth audience connected it to culture and to the sports that led it to a discovery. Inspired by the indiciary paradigm of Italian historian Carlo Ginzburg ${ }^{11}$, it is possible to see the connection between the newspaper-a systematic diffuser "youth rebellion" in Brazil and the world-and the emergence of the name Young Fans. It was during 1968 that these dissident fans emerged in Rio de Janeiro.

The inspiration of international slogan Youth Power was mediated by the Jornal dos Sports itself. Upon reading the newspaper, the favoritism, sympathy and coverage of the newspaper is clearly not only directed towards students, but to these Young Fans, with reports that highlight their actions.

Assimilating part of the effervescence of the time, fan groups such as Jovem-Flu, the Poder Jovem of Flamengo, and the Poder Jovem of Botafogo were born under the sign of rebellion and youth contestation. If the Charangas and the Organized Fans were restricted to the principle of giving "unconditional support" to the team, their dissidents, the "Young Fans", criticized the club management, they questioned the performance of teams and put the activities of the former fan leader of the same team in check. With this, they went back the initial design of organized fans, which was, until then, booing, holding demonstrations and protests.

In 1968 at the Maracanã, the fan groups repeated slogans from the student movement, with cries of: "the organized fans will topple the corrupt". Similar to the students involved in their marches, they performed symbolic of burials of the club management, when they sang: "Jornal dos Sports, with such great coverage, Jorge Veiga Brito, to the coffin quickly". Veiga Brito was the president of Flamengo, known by fans as the "Gravedigger of Flamengo", as a reporter for the Jornal dos Sports called him, in a series of stories published in the second half of 1968, with strong criticism directed towards his administration.

"People who make up the Young Fans of Flamengo, those that disagree with everything that is done at the club by Veiga Brito and Gunnar Göransson, were in the JS to greet the reporter Marcus Aurélio for his 'brilliant series of stories on the Gravediggers of Flamengo'. José Barbosa Viana, Reginaldo Mota and Gilberto Resende Correia, the oldest leaders of a very large group, made a point of clarifying that, depsite being club members, 'they will not go while Flamengo does not give them the same glory of times past. And they went beyond this: - we desire greatness for Flamengo and we do not care who is in charge of the club. From the way things are, it is hard to believe that Gunnar and Veiga Brito are able to raise the

${ }^{11}$ Ginzburg, C. Mitos, emblemas e sinais: morfologia e história. São Paulo: Companhia das Letras, 1989. 
team's morale. We have a lot of suffering to come, but our day is coming. This board of directors is terrible and we could only assess the mistakes made after the series of stories - The Gravediggers of Flamengo." ${ }^{2}$.

This breaking point seemed very serious in the battle for identity within the organized fans. The carnivalesque and family profile of the Charangas gave way to a more hegemonic youth/student profile, with the staging of a generational crisis within the groups.

After the AI-5, the name Youth Power disappeared from the newspaper and also from the stands, along with the depleting of the protests, which were circumstantial in nature. They only reappeared at the end of 1969, simply with the name Young Fans. Since the authority of the fan leader had been broken, a myriad of associations and leaders emerged in the 1970s, taking the form of tens and even hundreds of groups from the neighborhood, female groups, among others.

With the beginning of the National Brazilian League in 1971, the organized fans began promoting coaches going outside Rio, which increased their degree of cohesion and the level of their internal organization. Many also took part in Carnival, attending rehearsals held by the samba schools and taking percussion instruments inside the stadiums. The hymns and marches of the 1930s were replaced with long Samba-themed lyrics from the 1960s.

In 1972, MárioJúlio Rodrigues died as a result of alcohol-related problems. Although he left the Jornal do Sports to his son, Mário Rodrigues Neto, it became the possession of MárioJúlio's second wife.

Along with the new ownership, artistic and cultural material gradually disappeared from the content. The reports became restricted to being on the daily life of the students, with coverage on entrance exam preparations, among other instrumental and pragmatic aspects.

MárioJúlio Rodrigues' widow stayed in charge of the newspaper until 1980, when a new economic crisis put the paper into financial ruin. The newspaper was then sold to entrepreneur Arthur Sendas, owner of a chain of supermarkets called "Casas da Banha". Although it was still known by the slogan "the newspaper of Mário Filho", the editorial line was altered over time.

In any case, the policy of the jornal to give support to the fan groups would continue, taking the form of competitions and awards. However, at the end of the 1970s, the multiplication in the number of fan groups provided an approximation among them. In the early 1980s, they created a supporters association-the ASTORJ. The newspaper supported the initiative by granting a special column so that the entity could publish details of its activities.

The creation of the ASTORJ resulted in a wave of strikes by fans who were motivated by a controversial issue of the 1980s: the increase in the price of the tickets, which was derived from the high inflation in the so-called "Tempos das Aberturas". The Jornal dos Sports covered the demonstrations on its front page. The fans held a strike in the General sector of the Maracanã, in addition to having pickets outside the stadium and marches in front of the clubs' headquarters.

When describing this time of protest by the fans, it is possible to associate the protests of fan groups against the price of the tickets with a discussion by English historian E. P. Thompson regarding the idea of resistance and traditional popular culture. The peasants revolting against the rising price of wheat in $18^{\text {th }}$ century in England were decisively motivated by the idea of usurpation, in what the author calls the "moral economy of the crowd"13.

\footnotetext{
12 Jornal Dos Sports. 02 de outubro de 1968, p. 02.

13 Thompson, E. P. Costumes em comum. São Paulo: Companhia das Letras, 1998.
} 
During the 1980s, the fan groups moved away from the protest model and started being associated with groups of vandals and barbarians, the juvenile gangs, in the language of journalism, not just sporting, but more general as an environment. The increase in urban crime in Rio de Janeiro raised the "moral panic" level of society as a whole, along with the spread of alarming news regarding the growing violence. In soccer, journalists made the organized fans into a scapegoat for these violent events and the crisis in the sport. This stigma proved to be strong and long-lasting from his point on, with a wave of crimes and murders among the same Young Fans themselves.

\section{Organized Fans-Theories, Practices and Representations}

This final part of this article explores the theoretical dimensions regarding fan violence and builds general reflections about what I call the material and symbolic culture of soccer fans. This part seeks to reflect on the way in which fans rebuild, in their own way, the world of values that exist both in soccer as well as in society.

A first unavoidable point is the phenomenon of violence. To this end, some theories relating to violence can be built from Foucault's archaeological and genealogical model ${ }^{14}$. The French philosopher is opposed to the idea of origin used by traditional historians. Contrary to common sense, violence is seen as a structural and structuring principle of society. Since Simmel, and going onto Durkheim, sociology considers conflict as a disruptive element as well as an integrating one.

According to the anthropologist Luis Felipe Baeta Neves, a translator of Foucault's work, "the story, while being theoretical, does not consider the human out of duress, struggle, war, torture, brutal domination, hunger, and desperation" $" 15$.

Foucault does not go as far as simply glorifying the violent nature of the human condition. This appeared in the most radical dimension of the 1968 student movement. Part of it was even recovering the thought of Carl Schmitt or Georges Sorel. Foucault distanced himself from Hannah Arendt, since, for her, power and violence were antagonistic terms, with violent conduct being only destructive and instrumental, in their case-limits: "The extreme form of power is All against One, the extreme form of violence is One against All"16.

Along with these philosophical incursions, it is possible to follow the sociological discourse regarding violence in the followers of Norbert Elias, from the University of Leicester in England. Unlike Foucault, Eliasians understand to some extent the strange pleasure felt during fights between hooligans based on their social position: young tough classes from the British subproletariat. The sense of frustration and revenge towards the "included" was a failure of the civilizing project of the modern State.

However, decivilization was a momentary thing, from a particular historical time, in a long-term evolutionary path based on emotional self-control. Systematic aggression among the fan groups led to the creation of a rule of intergroup relationships, according to the famous 'Bedouin syndrome', coined by an English journalist: the friend of a friend is a friend; the enemy of a friend is an enemy; the enemy of an enemy is a friend; and the friend of an enemy is an enemy.

Syllogism uses the criteria of friendship and enmity as a standard for alliances and differences. Followers of Elias sought this "tribalistic" scheme in a report by an English journalist, in his article "Soccer's Tribal

\footnotetext{
${ }^{14}$ Foucault, M. Microfísica do poder. Rio de Janeiro: Graal, 1979.

15 Flores, L. F. B. N. "Da construção do conceito de violência". In: Pesquisa de Campo: Revista do Núcleo de Sociologia do Futebol. Rio de Janeiro: UERJ; SR-3, 1995, n. 2, p. 11.

16 Arendt, H. Sobre a violência. Rio de Janeiro: Relume-Dumará, 1994, p. 35.
} 
Wars", which was published in the New Society magazine in 1974. One primitivist metaphor was thusly used, namely the behavior of nomadic Arabs from North Africa to explain the logic of the organized fans in soccer.

The most entrenched theory to explain the organized fans is the crowd psychology, which was coined by Gustave Le Bon in the second half of the 19th century. It appears as a deciphering key for group human behavior. When immersed in the crowd, man is driven by wild and irrational attitudes, which he/she would never practice in everyday life. According to the philosopher, the crowd "constantly orients itself based on moral notions, images and sensations, in 'imaginationes', as well as on manifestations such as greed, wrath, envy and yearning for honor, and not on rational ideas".

Whereas historian CiroMarcondesFilho pondered the difficulty to understand the collective psychology resulting from the fact that the crowd is not a concept, but a way to react when faced with certain events. It tends to appear in other sectors that are not official policy: the fanaticism of sports crowds is one of their locus of expression.

This discourse was verbalized by representatives of the organized fans themselves:

I do not know any more if we, the organized fans, are a good or a bad thing for soccer. Because nobody hits another person because that person is wearing an another club's shirt. Of course, I am alone. Being in a group, the individual loses his reason, he becomes dangerous, creates courage and cowardice, hits a poor man with his son in his arm simply to show off. I am tired of stopping organized groups from flipping cars, breaking buses, and surrounding opposite fans. (Hélio Silva, former President of the Association of Organized Fan in the State of São Paulo). ${ }^{17}$

Violence by the mob is directed against those identified by fixed templates and "ready ideas": the scapegoats. In its original sense, these were ceremonies to discharge this collective anger. In the desacralized modern world, the scapegoat is manifested in the lynchings, the collective hysteria, the police chases, the gangs, the criminal damage, the vandalism, etc.

Unlike the irrationalism of crowd psychologists, my "genealogy of the moral supporter" accompanied a very specific documentary corpus: a series of letters from a sport column in the Jornal dos Sports.

Club identities are the source of moral affections and passions in the universe of fan groups. They are produced not only in the stadiums, but every day in letters published in the sporting journals, which is the space for discussions, where disagreements are resolved and real meetings are scheduled. Besides the verbalization, the "fan-scribblers" rationalize and justify, in their own way, the antipathies, the fights, and the enmities with opposing fan. They have created a dynamic for accusations and threats.

If the relationships between the players on the pitch were governed by universal rules and a control system placed above them, then the relationships between the fans in the stands would be autonomous to a certain extent, which is the result of local culture and a communicative morale itself. This can be seen in letters published in Jornal dos Sports. This newspaper was still trying to play referee, in order to promot contests, to reward the most animated groups and even to monitor the letters that arrived for publication in its reader column.

The logic of the fans did prevail by mimicking the tactical schemes, and by incorporating categories that are native to the playing field: the perseverance, determination, strength, honor. The agonistic dimension and male virility appear in the language of the letters as well as in the actions of the fan groups in the stands.

${ }^{17}$ Marcondes Filho, C. Violência das massas no Brasil. São Paulo: Global, 1986. 
Besides the violence, a second transgressive dimension in the lives of organized fans is the traveling coaches. The reports made the by journalists showed a narrative of the first systematic collective movement of fans at the beginning of the 1970s, in Brazil. The act of traveling in a group was still a novelty in soccer. This was established along with the creation of the National Soccer League. This integrated the various states in Brazil, with the scale and level of competition between the clubs being expanded.

The trips meant that there was greater structure within the fan groups. They have the connotation of a pilgrim "mission", with one aspect of altruism and another of hedonism. They produce cohesion of the group's internal links. At the same time, they highlight the need to interact with other groups of fans.

The coaches result in an extension of relationships between the fans and an emergence of alliances. The logic of these alliances is the aforementioned friendship-enmity dualism. This has three variants: 1) hospitality or hostility when receiving opposing fan groups;2) the degree of rivalry between the clubs at the time; and 3) personal contact between the leaders of each group.

Along with the violence and the coaches, the third crucial aspect of the fan group's material and symbolic culture is their linguistic and musical universe. Even if it only happens occasionally, this refers to the construction of a vocal culture in the groups. The craft seemed to be the key to preparing the repertoire and the vocabulary of the organized fans. The chanting and the slogans made by the fan groups vary from time to time. Some songs are kept, some are forgotten. However, it can be observed that they come from two basic sources: on the one hand, the epic ethos from the tradition of the clubs' martial hymns; on the other, the carnivalesque pathos that was absorbed by the mass culture in $20^{\text {th }}$ century Brazil ${ }^{18}$. From these, it is possible to include the carnival marches from the 1930s, the samba-plots from the 1960s, and the jingles played over the radio.

The parody technique incorporated popular music and songs into the repertoire of the associations. It is possible to see structurally that there is an adaptive and creative element to the fan groups. These fan groups are social bodies that establish new forms of communication through chanting, swearing, and using obscene words, which channels the polyphony of noisy sports arenas and imprints differentiated brands to the amorphous masses and the phenomenon of crowds. The public space in stadiums is suitable for the organized fan groups to create logic themselves, within the communicative structure of elementary questions and answers, which reveal his vital character that is always dynamic, unstable, and fluid.

\section{The Conclusion Mode}

As stated out at the beginning of this piece, these brief lines that give a general sense of the organized fan groups can be reconstituted not only through great narratives from the Jornal dos Sports. Besides the headlines and texts created by the writers, this reconstruction can be done by looking at the small letters section of the newspaper, entitled Bate-Bola, in which the fans left their messages and gave their opinions.

As in Wittgenstein's well-known axiom of, sports language can be read as a game and how to act. The "discursive practice" of the fans and their organizations gives a view into their daily lives. The letters section made it possible to observe the exchange of information and the groups' self-recognition, who would write and correspond with each other.

The fan groups were agents of a reality that was not only constructed in the stands, but also in the field of language, in the public space of the mass media. Thus, the column was more than mere conversation through

18 Wisnik, J. M. (1987). “Algumas questões de música e política no Brasil”. In: BOSI, A., A cultura brasileira: temas e situações. São Paulo: Ática. 
letters, it created an identity and a linguistic community. The announcements, the gatherings, the rivalries and the insults, in short, made up a whole chain of reciprocities, each one of which was opened by fans, in that microcosm and filter of social reality was the Jornal dos Sports.

\section{References}

Arendt, H. (1994). Sobre a violência. Rio de Janeiro: Relume-Dumará.

Aristóteles. Arte retórica e arte poética. Rio de Janeiro: Ediouro, s.d.

Bornheim, G. (1992). Brecht, a estética do teatro. Rio de Janeiro: Graal.

Bourdieu, P. (1983). Questões de sociologia. Rio de Janeiro: Marco Zero.

Burke, P., \& PORTER, R. (Orgs.). (1997). História social da linguagem. São Paulo: UNESP.

Carvalho, J. A. de. (1968). Torcedores de ontem e hoje. Rio de Janeiro: O Cruzeiro.

Castro, R. (1992). O anjo pornográfico - a vida de Nelson Rodrigues. São Paulo: Companhia das Letras.

Costa, A. L. (1995). A organização cordial: ensaio de cultura organizacional do Grêmio Gaviões da Fiel. In Revista de Administração de Empresas. São Paulo: s.e., , nov./dez.

Elias, N., \& Dunning, E. (1995). A busca da excitação. Lisboa: Difel.

Flores, L. F. B. N. (1995). Da construção do conceito de violência. In Pesquisa de Campo: Revista do Núcleo de Sociologia do Futebol. Rio de Janeiro: UERJ; SR-3, n. 2.

Foucault, M. (1979). Microfísica do poder. Rio de Janeiro: Graal.

Ginzburg, C. (1989). Mitos, emblemas e sinais: história e morfologia. São Paulo: Companhia das Letras.

Lopes, J. S. L. (1994). A vitória do futebol que incorporou a pelada. In: Revista USP-dossiê futebol. São Paulo.

Silva, E. M. (1999). A violência no futebol e a imprensa esportiva. In COSTA, MárciaRegina da (Org.), Futebol, espetáculo do século. São Paulo: Musa Editora.

Soares, L. E. (2000). Uma interpretação do Brasil para contextualizar a violência. In PEREIRA, Carlos AlbertoMesseder et al., Linguagens da violência. Rio de Janeiro: Rocco.

Thompson, E. P. Costumes em comum. São Paulo: Companhia das Letras.

Toledo, L. H. de. (1996). Torcidas organizadas de futebol. São Paulo: Autores Associados.

Toledo, L. H. de. (2002). Lógicas no futebol. São Paulo: hucitec.

Wisnik, J. M. In: Bosi, A., A cultura brasileira. São Paulo: Ática. 